\title{
PENGENALAN BUDAYA JEPANG MELALUI PERMAINAN MANNA SUGOROKU BAGI PEMBELAJAR BAHASA JEPANG TINGKAT DASAR
}

\author{
Nana Rahayu \\ Program Studi Pendidikan Bahasa Jepang FKIP Universitas Riau \\ email: nana_rh12@yahoo.com
}

\begin{abstract}
ABSTRAK. Pada umumnya mahasiswa yang masuk ke Program Studi Pendidikan Bahasa Jepang FKIP Universitas Riau memiliki minat yang tinggi terhadap budaya Jepang. Sehingga pengenalan masyarakat dan budaya Jepang disajikan dalam bentuk matakuliah Nihon Jijou pada semester 1. Bagi mahasiswa atau pembelajar bahasa Jepang tingkat dasar, pengenalan budaya Jepang ini memberikan motivasi tersendiri untuk belajar bahasa Jepang. Hanya saja pemahaman budaya Jepang tersebut hanya mereka dapati dalam materi perkuliahan tanpa merasakan langsung seperti apa budaya Jepang dalam keseharian orang Jepang. Salah satu pengenalan budaya Jepang adalah memahami cara atau sikap masyarakat Jepang ketika menggunakan transportasi umum khususnya kereta melalui permainan Manna Sugoroku. Untuk memahaminya mahasiswa diminta membaca huruf Jepang yang merupakan salah satu penghambat bagi mahasiswa untuk bisa memahami budaya Jepang dengan baik.. Melalui permainan Manna Sugoroku mahasiswa diharapkan dapat membaca aturan dalam permainan tersebut yang menggunakan huruf Jepang sehingga mahasiswa secara mandiri memperoleh pengenalan budaya Jepang yang belum pernah mereka ketahui sebelumnya dan mahasiswa termotivasi belajar bahasa Jepang dengan meningkatkan kemampuan membaca huruf Jepang.
\end{abstract}

Kata kunci : budaya Jepang, permainan, pembelajar bahasa Jepang tingkat dasar

\section{RECOGNITION OF JAPANESE LANGUAGE THROUGH MANNA SUGOROKU GAMES FOR BASIC LEVEL STUDENTS OF JAPANESE LANGUAGE}

\begin{abstract}
Generally, students who enter the Japanese Language Education Study Program Faculty of Teacher Training and Education Riau University have a high interest in Japanese Culture. So that, the introduction of Japanese society and culture is presented in the form of Nihon Jijou subjects in semester 1. For the students or Japanese learners at the basic level, the introduction Japanese culture provides its own motivation in learning Japanese. It is just that their understanding of Japanese culture is only found in the material without feeling directly what Japanese culture is like in everyday Japanese life. One of the Japanese culture introductions is to understand the ways or the attitude of Japanese people when using public transportation, especially trains through the Manna Sugoroku game. To understand this, students are asked to read Japanese letters which is one of the obstacles for students to understand Japanese culture well. Through Manna Sugoroku game students were expected to be able to read the rules using Japanese letter so students independently acquire an introduction to Japanese culture that they have never been known before and students were motivated to learn Japanese by increasing their ability in reading Japanese letter.
\end{abstract}

Keywords: Japanese culture, Game, Basic level Japanese learners 


\section{PENDAHULUAN}

Pembelajar bahasa Jepang di Program Studi Pendidikan Bahasa Jepang FKIP Universitas Riau secara tidak langsung mendapatkan pengenalan budaya Jepang pada hampir seluruh matakuliah yang diberikan. Seperti pada matakuliah Membaca Pemahaman (Dokkai) yang isi dari teks bacaannya tidak terlepas dengan budaya masyarakat Jepang sehari-hari. Begitu juga dengan matakuliah Menyimak (Choukai) yang materinya tentang kejepangan dan matakuliah-matakuliah lainnya.

Tujuan memasukkan budaya Jepang dalam materi matakuliah di samping buku sumber berasal dari penerbit di Jepang adalah agar pembelajar bahasa Jepang Program Studi Pendidikan Bahasa Jepang FKIP Universitas Riau dapat mengenal masyarakat Jepang dalam kehidupan seharihari. Seperti yang disebutkan oleh Wilhem von Humboldt dalam Dardjowidjojo (2003) bahwa bahasa di dunia pasti merupakan perwujudan budaya dari masyarakat penutunya. Oleh karena itu bahasa dan budaya memiliki hubungan yang sangat erat. Hubungan yang erat tersebut dapat diterjemahkan bahwa adanya ketergantungan pemikiran manusia pada bahasa. Maksudnya adalah pandangan hidup dan budaya suatu masyarakat ditentukan oleh bahasa masyarakat itu sendiri.

Menurut Mustakin dalam papernya menyatakan bahwa bahasa pada dasarnya tidak terlepas dari konteks sosial masyarakat penuturnya karena selain merupakan fenomena sosial, bahasa merupakan bentuk perilaku sosial yang digunakan sebagai sarana komunikasi dengan melibatkan sekurang-kurangnya dua orang peserta. Oleh karena itu berbagai faktor sosial yang berlaku dalam komunikasi seperti hubungan pembicara dalam komunikasi, tempat komunikasi, status sosial, pendidikan, usia, jenis kelamin juga berpengaruh dalam penggunaan bahasa.

Sebagai contoh budaya Jepang yang juga secara langsung dipelajari dalam bahasa Jepang adalah Keigo. Keigo adalah ungkapan sopan yang dipakai pembicara atau penulis dengan mempertimbangkan pihak pendengar, pembaca atau orang yang menjadi pokok pembicaraan (Ogawa dalam Sudjianto 2004). Ragam bahasa sopan yang digunakan pembicara terhadap lawan bicara atau orang ketiga yang menjadi topik pembicaraan itersebut memiliki tiga faktor yang harus diperhatikan, yaitu (1) menunjukkan rasa hormat pembicara terhadap lawan bicara yang statusnya lebih tinggi (2) menunjukkan rasa hormat pembicara ketika belum saling akrab dengan lawan bicara dan (3) digunakan dengan memperhatikan hubungan sosial di luar lingkungan sendiri.

Adanya perbedaan-perbedaan sosial pada masyarakat Jepang sebagai masyarakat sosial mempengaruhi masyarakat Jepang itu sendiri dalam memilih kata dalam berkomunikasi khususnya dengan menggunakan keigo. Hal tersebut dilatarbelakangi oleh beberapa faktor yaitu faktor yang berkaitan dengan identitas sosial penutur, jarak sosial dan jarak psikologis (Bunka Shingikai, 2007).

Selain keigo, contoh nyata budaya Jepang yang dapat langsung dipelajari oleh mahasiswa adalah Aisatsu dan Ojigi. Ketika saling bertemu, masyarakat Jepang saling bertegur sapa mengucapkan salam (aisatsu) 
sambil membungkukkan badan (ojigi). Di samping itu aisatsu memiliki ungkapan dan eskpresi yang berbeda. Kedua hal tersebut sangat berbeda dengan budaya Indonesia, dimana masyarakat Indonesia pada umumnya ketika bertemu dengan orang lain, menyapa, mengucapkan salam sambil berjabatan tangan.

Dari penjelasan singkat tentang keigo, aisatsu dan ojigi tersebut dapat terlihat bagaimana masyarakat Jepang ketika berinteraksi atau berkomunikasi dengan orang lain terlebih kepada orang yang baru dikenal menggunakan bahasa sopan sebagai bentuk hormat kepada lawan bicaranya. Hal tersebut terlihat bahwa bahasa dan budaya merupakan satu kesatuan yang tidak dapat dipisahkan. Pembelajar bahasa Jepang dapat secara langsung mempelajarinya dengan mempraktekkan pada matakuliah Berbicara (Kaiwa) atau melihat dan mendengar langsung dari anime / lagu yang mereka gemari.

Untuk mengetahui dan memahami bahasa Jepang hingga dapat berkomunikasi dengan baik, pembelajar bahasa Jepang khusunya mahasiswa program studi pendidikan bahasa Jepang FKIP Universitas Riau secara tidak langsung juga mempelajari budaya Jepang. Kurikulum program studi Pendidikan Bahasa Jepang FKIP Universitas Riau berbasis KKNI tahun 2014 mengacu kepada misi program studi. Misi tersebut menjadi poin penentu dalam menghasilkan lulusan. Capaian lulusan yang diharapkan adalah sebagai pengajar bahasa Jepang, peneliti kejepangan dan pelaku budaya Indonesia dan Jepang yang berarti setelah mereka lulus diharapkan dapat menjadi penerjemah, tour guide, dan lain sebagainya. Pekerjaan-pekerjaan seperti itu membutuhkan pengertian dan pemahaman yang baik tentang budaya Jepang.

Matakuliah yang menyediakan materi khusus pengenalan budaya Jepang pada Program Studi Pendidikan Bahasa Jepang FKIP Unversitas Riau ada pada matakuliah Nihonjijou (Pengantar Kejepangan) yang diberikan pada semester 1. Selanjutnya, materi yang lebih dalam tentang budaya Jepang disajikan pada matakuliah pilhan Masyarakat, Budaya dan Sastra Jepang dan Ibunka Communication di semester 7 . Namun demikian tidak tertutup kemungkinan pada setiap matakuliah berbahasa Jepang pada Program Studi Pendidikan Bahasa Jepang FKIP Universitas Riau dosen pengampu menyisipkan sedikit pengetahuan tentang budaya Jepang yang berkaitan dengan apa yang sedang dipelajari saat itu.

Program studi Pendidikan Bahasa Jepang FKIP Universitas Riau selama ini tidak memiliki bahan ajar yang tetap untuk materi perkuliahan Nihonjijou. Akan tetapi, berdasarkan deskripsi matakuliah yang sudah ditetapkan pada Kurikulum Berbasis KKNI FKIP Universitas Riau 2014 dosen pengampu diberikan kebebasan dalam menentukan materi yang akan diberikan kepada mahasiswa. Materi tersebut menyesesuaikan dari beberapa sumber bacaan baik dari buku, majalah ataupun media internet. Selama ini, materi perkuliahan Nihonjijou diberikan melalui metode ceramah menggunakan media powerpoint dan diakhir perkuliahan terkadang mahasiswa diberikan tugas mandiri dan kelompok yang kemudian pada 
pertemuan berikutnya tugas tersebut dipresentasikan. Hal tersebut kadangkala memberikan rasa jenuh terhadap mahasiswa karena materi perkuliahan yang monoton.

\section{Tujuan Penelitian}

Tujuan penelitian ini adalah untuk memberikan salah satu contoh penggunaan media dalam pembelajaran Nihonjijo yaitu media permainan. Dimana dengan permainan Manna Sugoroku yang diperkenalkan kepada mahasiswa Program Studi Pendidikan Bahasa Jepang FKIP Universitas Riau khususnya dapat langsung menyerap aturanaturan yang harus ditaati ketika menggunakan fasilitas umum (kereta) dari permainan tersebut. Sehingga diharapkan mahasiswa Program Studi Pendidikan Bahasa Jepang FKIP Universitas Riau yang telah mendapatkan pengetahuan dari permainan tersebut dapat membagi ilmunya kepada masyarakat di lingkungan terdekatnya.

\section{Kontribusi Penelitian}

Peneiltian ini ditujukan kepada guru-guru atau dosen pengampu matakuliah Nihonjijo atau sejenisnya karena dapat digunakan sebagai salah satu contoh menggunakan media permainan dalam pembelajaran.

\section{Kajian Teoritis}

1. Motivasi Belajar

Menurut Hamzah B. Uno (2011) motivasi belajar adalah dorongan internal dan eksternal pada siswa yang sedang belajar yang pada umumnya ditandai dengan beberapa indikator atau unsur-unsur yang mendukung indikator-indikator tersebut.
Antara lain: adanya hasrat dan keinginan berhasil, dorongan dan kebutuhan dalam belajar, harapan dan cita-cita masa depan, penghargaan dalam belajar, dan lingkungan belajar yang kondusif.

Sejalan dengan pendapat di atas, Sardiman dalam buku Interaksi dan Motivasi Belajar Mengajar (2016) menuliskan bahwa motivasi berasal dari kata "motif" yang dapat diartikan sebagai daya penggerak yang ada di dalam diri seseorang untuk melakukan aktivitas-aktivitas tertentu demi tercapainya tujuan. Adapun ciri pokok dalam motivasi adalah diawali dengan terjadinya perubahan energi, ditandai dengan adanya feeling dan dirangsang karena adanya tujuan.

Dalam kegiatan belajar, motivasi dapat dikatakan sebagai keseluruhan daya penggerak di dalam diri siswa yang menimbulkan, menjamin kelangsungan dan memberika arah kegiatan belajar, sehingga diharapkan tujuan dapat tercapai. Motivasi selalu berkaitan dengan kebutuhan, salah satunya adalah kebutuhan untuk mencapai hasil. Dalam hal ini adalah kebutuhan siswa akan mencapai nilai yang baik. Bentuk motivasi dalam belajar terdiri antara lain: memberi angka, hadiah, ego-involvement, memberi ulangan, mengetahui hasil, pujian, hukuman, hasrat untuk belajar dan minat.

Menurut Hamzah B. Uno, peran penting motivasi belajar dan pembelajaran, antara lain:

1) Peran motivasi belajar dalam menentukan penguatan belajar. Motivasi dapat berperan dalam penguatan belajar apabila seseorang anak yang sedang belajar dihadapkan pada suatu masalah yang menentukan 
pemecahan dan hanya dapat dipecahkan berkat bantuan hal-hal yang pernah dilalui.

2) Peran motivasi dalam memperjelas tujuan belajar. Peran motivasi dalam memperjelas tujuan belajar erat kaiatannya dengan kemaknaan belajar. Anak akan tertarik untuk belajar sesuatu, jika yang dipelajari itu sedikitnya sudah dapat diketahui atau dinikmati manfaatnya oleh anak.

3) Motivasi menentukan ketekunan belajar. Seorang anak yang telah termotivasi untuk belajar sesuatu berusaha mempelajari dengan baik dan tekun dengan harapan memperoleh hasil yang lebih baik.

Dengan demikian dapat disimpulkan bahwa peran motivasi belajar adalah sebagai pendorong usaha untuk pencapaian prestasi sehingga untuk mencapai prestasi tersebut peserta didik dituntut untuk menentukan sendiri perbuatan-perbuatan apa yang harus dilakukan untuk mencapai tujuan belajarnya.

Sehingga seseorang yang memiliki tujuan dalam belajarnya dapat diartikan ia juga memiliki motivasi dalam belajar. Hal tersebut dalapat dilihat melalui ciriciri seseorang yang memiliki motivasi dapat diklasifikasikan sebagai berikut:

1) Adanya hasrta dan keinginan untuk berhasil.

2) Adanya dorongan dan kebutuhan dalam belajar.

3) Adanya harapan dan cita-cita di masa depan.

4) Adanya penghargaan dalam belajar.
5) Adanya kegiatan yang menarik dalam belajar.

6) Adanya lingkungan belajar yang kondusif, sehingga memungkinkan seorang siswa dapat belajar dengan baik.

Dengan demikian, apabila siswa memiliki ciri-ciri seperti yang disebutkan di atas, berarti siswa tersebut memiliki motivas yang cukup kuat. Siswa yang memiliki motivasi belajar yang tinggi akan memiliki beberapa ciri yang membedakan dirinya dengan siswa yang memiliki motivasi belajar rendah.

Mulyasa (2005) menyebutkan bahwa prinsip yang dapat diterapkan untuk meningkatkan motivasi belajar adalah sebagai berikut:

1) Peserta didik akan lebih giat apabila topik yang akan dipelajari menarik dan berguna bagi dirinya.

2) Tujuan pembelajaran disusun secara jelas dan diinformasikan kepada peserta didik agar mereka mengetahui tujuan belajar tersebut.

3) Peserta didik selalu diberi tau tentang hasil belajarnya.

4) Pemberian pujian dan reward lebih baik daripada hukuman, tapi sewaktuwaktu hukuman juga diperlukan.

5) Memanfaatkan sikap, cita-cita dan rasa ingin tahu peserta didik.

6) Usahakan untuk memperhatikan perbedaan peserta didik, misalnya perbedaan kemauan, latar belakang dan sikap terhadap subjek tertentu.

7) Usahakan untuk memenuhi kebutuhan peserta didik dengan selalu memperhatikan mereka dan mengatur 
pengalaman belajar yang baik agar siswa memiliki kepuasan dan penghargaan serta mengarahkan pengalaman belajarnya ke arah keberhasilan sehingga memiliki kepercayaan diri dan tercapainya prestasi belajar.

\section{Pembelajaran Nihonjijou}

Konsep pembelajaran Nihonjijou yang digunakan dalam penelitian ini adalah konsep yang disampaikan oleh salah satu tenaga pengajar yaitu Kitamura Takeshi ketika penulis belajar di The Japan Foundation Urawa Center.

Dalam pembelajaran Nihonjijou, tujuan utama bukanlah menjadikan mahasiswa sebagai peneliti kejepangan atau ahli kejepangan, melainkan diharapkan dapat meningkatkan kemampuan berbahasa Jepang, dapat berkomunikasi dengan orang Jepang dan dapat mengerti tentang budaya Jepang. Berdasarkan penilaian angket yang disebarkan sebelum pembuatan Erin Ga Chousen!. Di luar Jepang, pembelajar bahasa Jepang masih sedikit yang memperoleh informasi tentang Jepang. Oleh karena itu mereka memiliki keingintahuan yang kuat tentang kehidupan sehari-hari orang Jepang. Apabila mereka telah mendapatkan infromasi tersebut maka keingintahuan mereka tidak lagi sebata hanya pada kehidupan orang Jepang sehari-hari melainkan kepada apa yang dipikirkan oleh orang Jepang, permasalahan yang dihadapi oleh orang Jepang, teknologi, hubungan kemasyarakatan dan lain sebagainya. Sehingga pembelajar bahasa Jepang terutama di Indonesia membutuhkan informasi berupa gambar, video dan lain-lain yang menunjukkan kehidupan nyata orang Jepang.

Dalam pembelajaran bahasa asing dalam hal ini bahasa Jepang terdapat 5 (lima) target yang diharapkan tercapai yaitu:

a. Communication (コミュニケーション), diharapkan pembelajar dapat berkomunikasi dengan bahasa Jepang.

b. Cultures ( 文 化), dapat memahami kebudayaan Jepang dengan baik.

c. Connections (コネクション),dengan kemampuan bahasa Jepang dapat menyerap dan menerima pengetahuan lain.।

d. Comparison ( 比 較 ), dapat membandingkan bahasa Jepang dengan bahasa ibu, sehingga dapat menambah wawasan tentang bahasa dan budaya masing-masing.

e. Communities (コミュニティ), dapat bergabung dengan kelompok-kelompok budaya yang menggunakan bahasa Jepang baik dalam dan luar negeri.

Pada point nomor 2, yaitu dapat memahami kebudyaan Jepang. Dalam hal ini karena budaya Jepang unik dan banyak pembelajar bahasa Jepang yang tertarik. Oleh karena itu pembelajar bahasa Jepang seharusnya juga memiliki pengetahuan tentang kebudyaan tradisional dan kebudayan kontemporer. Kemudian, diharapkan kepada pembelajar bahasa Jepang memiliki pemikiran bahwa kebudyaan adalah sebuah organisasi yang tersusun rapi dan perlu mengetahui aturan untuk memahami budaya tersebut.

Pada budaya, terdiri dari masyarakat yang melaksanakan adat dan kebiasaan dan 
tempat tinggal sebagai hasil dari budaya tersebut. Kemudian dua hal tersebut melatarbelakangi adanya pemikiran dan cara pandang serta penilaian seseorang terhadap budaya.

Dapat dilihat dari bagan berikut:

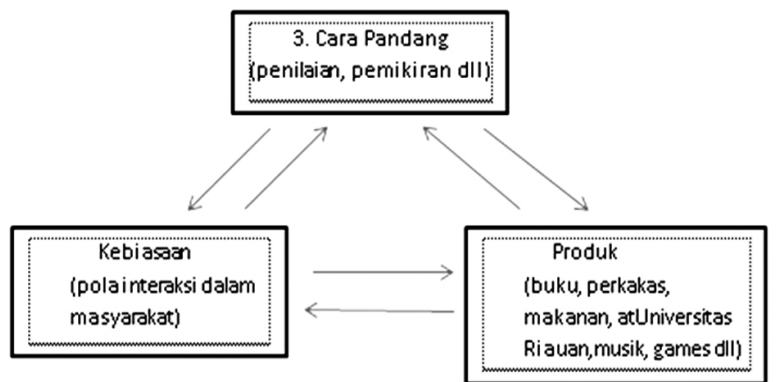

Sumber: The Japan Foundation, Urawa.

Dari bagan tersebut setelah melihat dan mencoba secara langsung serta menganalisis (1) dan (2), maka nomor (3) dapat dipahami dengan dengan baik. Dengan kata lain, pembelajar bahasa Jepang dapat melihat sendiri secara langsung dan dapat berpikir sendiri.

Pembelajar bahasa Jepang di Program studi Pendidikan Bahasa Jepang FKIP Universitas Riau mendapatkan informasi tentang Jepang pada umumnya melalui media elektronik dan media cetak, buku pelajaran, perkumpulan atau klub, orang Jepang yang ada di Pekanbaru atau Riau, website dan fotofoto atau video yang diambil langsung oleh dosen pengajar ketika sedang berada di Jepang. Beberapa benda tersebut dapat dijadikan media dalam pembelajaran. Diantaranya adalah:

\section{a. Foto}

Dalam pembelajaran foto yang digunakan dapat berupa foto yang diambil sendiri ataupun dari beberapa sumber lain salah satunya adalah website. Sambil memperlihatkan foto, guru/dosen pengajar tanpa menjelaskan apa yang dapat dilihat dari foto tersebut meminta pembelajar untuk berfikir namun sebelumnya guru/dosen menyiapkan beberapa pertanyaan berkaitan dengan apa yang dilihat dari foto tersebut.

Akan tetapi, menggunakan foto sebagai media dalam pembelajaran memiliki kelebihan dan kekurangan sendiri. Kelebihannya adalah secara nyata dapat dilihat, dibayangkan dan dikonfirmasi, mudah dibawa dan dapat diperlihatkan secara berkali-kali. Sedangkan kekurangannya adalah: banyak informasi selain apa yang ingin disampaikan dan sudah pasti karena hanya sebagai foto maka pergerakan dari apa yang diperlihatkan tidak dapat dimengerti oleh pembelajar. Apabila hanya 1 lembar foto yang diperlihatkan maka perhatian pembelajar hanya terpaku kepada foto tersebut.

\section{b. Video}

Hampir sama dengan foto, penggunaan video dalam pembelajaran bahasa Jepang dapat diperoleh melalui website ataupun merekam video tersebut sendiri. Seperti halnya foto, video juga memiliki kelebihan dan kekurangannya. Dimana kelebihan dari penggunaan video adalah pembelajar dapat mengerti pergerakan, pergantian dari video tersebut serta keadaan sekeliling dari apa yang menjadi pusat pembicaraan dapat terlihat dengan jelas. Seperti misalnya, cara makan orang Jepang, cara menggunakan sumpit oleh orang Jepang dan lain sebagainya. Sedangkan kekurangannya adalah perhatian pembelajarn dapat dengan mudah berpindah dari apa yang menjadi poin 
dalam video yang diperlihatkan oleh guru/dosen pengajar.

\section{c. Realia}

Dalam istilah pembelajaran, Realia adalah benda/objek yang dipergunakan adalah benda nyata yang didapat dari lingkungan sekitar. Dengan kata lain media yang dipergunakan dalam pembelajaran bukanlah yang media yang sengaja dibuat atau dipersiapkan oleh guru/dosen. Dikarenakan realia ini dapat diperoleh di lingkungan sekitar, guru/dosen dapat mengumpulkannya sesuai dengan kebutuhan pembelajaran. Keuntungan dari realia adalah dapat menimbulkan minat pembelajar, pembelajar dapat langsung merasakan keadaan secara nyata. Sebagai contoh, kehidupan di Jepang dan budaya Jepang dapat terlihat secara langsung. Namun demikian penggunaan realia ini juga memiliki kekurangan salah satunya adalah minat pembelajar yang terlalu luas sehingga apa yang telah direncanakan dalam rancangan pembelajaran dapat terganggu.

\section{Media Pembelajaran}

Rusman (Belajar dan Pembelajaran, 2017) mengatakan bahwa media pembelajaran merupakan salah satu komponen proses belajar mengajar yang memiliki peranan sangat penting dalam menunjang keberhasilan proses belajar mengajar. Hal tersebut sejalan dengan yang dikatakan oleh Gagne (Ali dalam Rusman, 214) mengatakan bahwa media adalah berbagai jenis komponen dalam lingkungan siswa yang dapat memberikan rangsangan untuk belajar.
Media pembelajaran merupakan suatu teknologi pembawa pesan yang dapat digunakan untuk keperluan pembelajaran, media pembelajaran merupakan saarana fisik untuk menyapaikan materi pelajaran. Media pembelajaran merupakan sarana komunikasi dalam bentuk cetak maupun pandang dengar termasuk teknologi perangkat keras.

Pada awal sejarah pembelajaran, media hanya sebagai alat bantu yang digunakan oleh guru untuk menyampaikan pelajaran. Berbeda dengan saat ini, kehadiran media pembelajaran juga dapat memberikan dorongan, stimulus, pengembangan aspek intelektual, maupu emosional siswa. Sehingga pada hakikatnya media pembelajaran sebagai wahan untuk menyampaikan pesan atau informasi dari sumber pesan diteruskan pada penerima. Pesan atau disebut juga dengan bahan ajar yang disampaikan adalah materi pembelajaran yang telah dirumuskan, sehingga dalam prosesnya memerlukan media sebagai subsistem pembelajaran.

Pemanfaatan media sangat tergantung pada karakterisitik media dan kemampuan guru maupun siswa memahami cara kerja media tersebut, sehingga pada akhirnya media dapat digunakan dan dikembangkan sesuai dengan tujuan pembelajaran yang diharapkan. Penggunaan media itu sendiri dimaksudkan agar siswa mampu menciptakan sesuatu yang baru dan mampu memanfaatkan sesuatu yang telah ada untuk digunakan dengan bentuk dan variasi lain yang berguna dalam kegiatan belajarnya. Dengan demikian, mereka akan dengan mudah mengerti dan memahami materi 
pelajaran yang disampaikan oleh guru maupun kelompoknya.

Dari pandangan yang di atas dapat dikatakan bahwa media merupakan alat yang memungkinkan siswa untuk emngerti dan memahami sesatu dengan mudah untuk mengingatnya dalam waktu yang lama dibandingkan dengan penyampaian materi pelajaran dengan cara tatap muka dan ceramah anpa alat bantu atau media pembelajaran.

\subsection{Fungsi Media Pembelajaran \\ Media pembelajaran memiliki fungsi} yang sangat strategis dalam pembelajaran. Sering kali terjadi beanyaknya siswa yang tidak atau kurang memahami materi pelajaran yang disampaikan oleh guru atau - kompetensi yang diberikan pada siswa dikarenakan ketiadaan atau kurang optimalnya pemberdayaan media pembelajaran dalam proses belajar mengajar. ada beberapa fungsi media pembelajaran diantaranya:

1) Sebagai alat bantu dalam proses pembelajaran, yaitu alat bantu yang dapat memperjelas, mempermudah, mempercepat penyampaian pesan atau materi pelajaran kepada siswa sehingga inti materi pelajaran secara utuh dapat disampaikan pada siswa.

2) Sebagai komponen dari sub sistem pembelajaran, yaitu suatu sistem yang mana di dalamnya memiliki sub-sub komponen di antaranya komponen media pembelajaran.

3) Sebagai pengarah dalam pembelajaran, yaitu sebagai pengarah pesan atau materi apa yang aka disampaikan, atau kompetensi apa yang akan dikembangkan untuk dimiliki siswa.

4) Sebagai permainan atau membangkitkan perhatian dan motivasi siswa, yaitu dapat membangkitkan perhatian dan motivasi siswa dalam belajar, karena media pembelajaran dapat mengakomodasi semua kecakapan siswa dalam belajar. Media pembelajaran dapat memberikan bantuan pemahaman pada siswa yang kurang memiliki kosentrasi dalam belajar.

5) Meningkatkan hasil dan proses pembelajaran. Secara kualitas dan kuantitas media pembelajaran sangat memberikan kontribusi terhadap hasil maupun proses pembelajaran.

6) Mengurangi terjadinya verbalisme, yaitu apa yang diterangkan atau dijelaskan oleh guru lebih bersifat absrtak atau tidak ada wujud, tidak ada ilustrasi nyata sehingga siswa hanya dapat menyebut tampa memahami bentuk.

7) Mengatasi keterbatasan ruang, waktu , tenaga, dan daya indra. Sering terjadi dalam pembelajaran menjelaskan pembelajaran uang sifatnya sangat luas dan lebar atau sempit, sehingga memerlukan alat bantu untuk menjelaskan, mendekatkan pada objek yang dimaksud.

Dalam hal ini berpegang pada fungsi pembelajaran poin $\mathrm{d}$, maka penulis menggunakan permainan dalam pembelajaran $\mathrm{Ni}$ honjijou agar siswa lebih paham tentang budaya Jepang sehingga daat menimbulkan gairah dan motivasi untuk lebih giat belajar bahasa Jepang melalui permainan. 


\subsection{Manna Sugoroku}

Sugoroku adalah istilah laih dalam bahasa Jepang untuk sebutan permainan seperti ular tangga. Berdasarkan informasi yang di dapat melalui situs Wikipedia, permainan ular tangga dalah permainan papan untuk anakanak yang dimainkan 2 orang atau lebih. Papan permainan dibagi dalam kotak-kotak kecil dan di beberapa kotak digambar sejumlah tangga atau ular yang menghubungkan dengan kotak lain.

Berikut adalah contoh permainan Manna Sugoroku dengan tema mari mematuhi aturan dalam berkereta di Jepang.
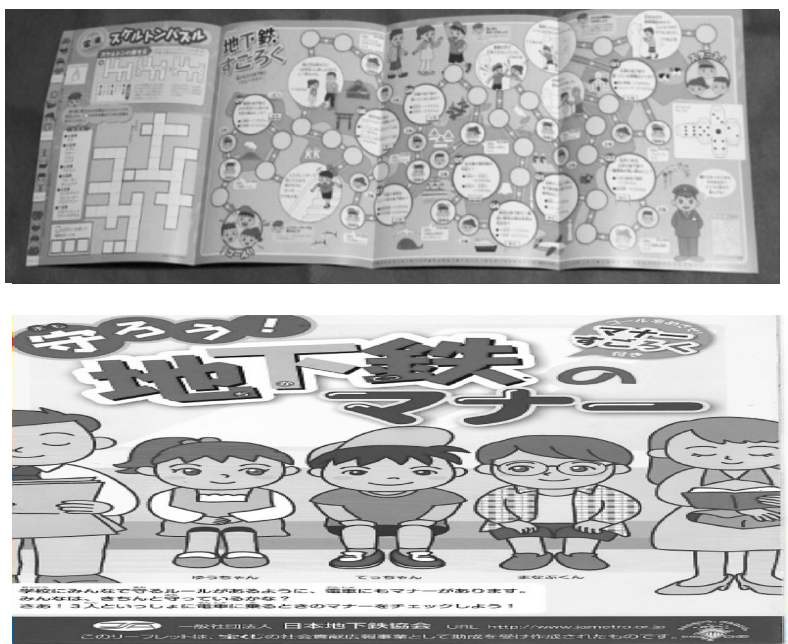

Gambar 1 dan 2. Papan Permainan Manna Sugoroku

Tidak ada permainan standar dalam ular tangga. Setiap orang dapat menciptakan papan mereka sendiri dengan jumlah kotak, ular dan tangga yang berlainan. Setiap pemain mulai dengan bidaknya di kotak pertama (biasanya kotak di sudut kiri bawah) dan secara bergiliran melemparkan dadu. Bidak dijalankan sesuai dengan jumlah mata dadu yang muncul. Bila pemain mendarat di ujung bawah tangga,, mereka dapat langsung pergi ke ujung tangga yang lain. Bila mendarat di kotak dengan ular, mereka harus turun ke kotak di ujung bawah ular. Pemenang adalah pemain pertama yang mencapat kotak terakhir. Biasanya bila seorang emain mendapatkan angka 6 dari mata dadu, mereka mendapat giliran sekali lagi, bila tidak, maka giliran jatuh ke pemain selanjutnya.

Begitu juga halnya dengan permainan Manna Sugoroku yang digunakan penelitian ini penulis dapatkan secara gratis di stasiun kereta Kobe sebagai realia ketika menjadi peserta pelatihan di The Japan Foundation, Urawa Center. Brosur/pamflet dari pemerintah kota Kobe yang berisikan tentang aturan-aturan yang harus ditaati ketika menggunakan kereta/chikatetsu. Dengan tujuan, seluruh masyarakat terutama pelajar yang dikemas dalam bentuk permainan sugoroku. Oleh karena kereta adalah transportasi yang hampir seluruh masyarakat Jepang menggunakannya maka melalui permainan ini pembelajar bahasa Jepang Program Studi Pendidikan FKIP Universitas Riau dapat mengetahui secara langsung aturan yang ada ketika menaiki kereta meskipun mereka sama sekali belum pernah menaiki secara langsung. Diharapkan dengan permainan Manna Sugoroku ini mahasiswa Prodi Pendidikan Bahasa Jepang FKIP Univerasitas Riau tidak hanya dapat meningkatkan motivasi belajar bahasa Jepang mereka terutama membaca huruf Jepang yang harus mereka baca sebagai petunjuk dalam permainan Manna Sugoroku tersebut.

\section{Metode}

Metode yang digunakan dalam penelitian ini adalah metode deskriptif. Penelitian deskriptif adalah penelitian yang dimaksudkan untuk menyimpulkan informasi mengenai status gejala yang ada, yaitu gejala 
menurut apa adanya pada saat penelitian dilakukan (Arikunto, 2007).

Penelitian ini dilakukan dalam dua tahap yaitu :

1. Tahap Pendahuluan

a. Pada tahap ini penulis menseleksi mahasiswa baru program studi Pendidikan Bahasa Jepang FKIP Universitas Riau angkatan 2017 yang sudah pernah belajar bahasa Jepang sebelumnya baik di SMA maupun di lembaga kursus. Dari 72 orang mahasiswa baru tersebut 20 orang mahasiswa terpilih untuk mengikuti kegiatan ini dan mereka belum mengikuti perkuliahan Nihonjijou. Selain mahasiswa angkatan 2017, mahasiswa angkatan 2016 juga dilibatkan sebanyak 20 orang. Dimana, mahasiswa tersebut sudah pernah belajar Nihonjijou di semester 1 tetapi belum pernah mengetahui tentang permainan Manna Sugoroku.

b. Setelah terkumpul mahasiswa angkatan 2017 dan 2016 sebanyak 40 orang, penulis memperlihatkan materi pengantar berupa slide PPT. Sebelum memperkenalkan permainan tersebut, penulis memperlihatkan gambar dan mahasiswa membayangkan gambar tersebut. Setelah mereka dapat menebak gambar pertama yang diperlihatkan dan memahami materi yang diberikan tentang aturan yang harus dipatuhi oleh orang Jepang ketika menggunakan fasilitas umum terutama kereta. Selanjutnya penulis memberikan tugas untuk mencari sebanyak-banyaknya informasi mengenai aturan yang harus dipatuhi ketika menaiki kereta agar lebih mudah mengikuti kegiatan permainan Manna Sugoroku.

2. Tahap pelaksanaan

Tahap pelaksanaan ini dilaksanakan pada hari berikutnya dengan mahasiswa yang sama seperti hari sebelumnya. Pada tahap ini mahasiswa dibagi menjadi 10 kelompok yang beranggotakan 4 orang secara acak. 3 orang yang akan bermain dan 1 orang bertindak sebagai penilai dikarenakan mahasiswa yang ikut dalam kegiatan ini sebagian besar belum lancar membaca huruf bahasa Jepang. Masingmasing kelompok diberikan satu buah papan permainan Manna Sugoroku, 1 buah dadu (さいころ) dan 3 buah $\operatorname{bidak}(コ マ$ ). Selanjutnya mereka memainkan permainan seperti halnya bermain ular tangga. Hanya saja dalam permainan Manna Sugoroku ini mahasiswa dituntut untuk membaca setiap pertanyaan atau pernyataan yang ada tersedia pada kotak sugoroku. Apabila dapat menjawab pertanyaan atau menyatakan pernyataan tersebut benar atau salah maka 1 orang mahasiswa sebagai penilai menentukan apakah mahasiswa tersebut dapat melanjutkan atau 1 kali putaran istirahat.

Setelah menyelesaikan permainan Manna Sugoroku ini, mahasiswa diberikan kertas kecil dan diminta untuk menuliskan pelajaran apa yang mereka dapati dari permainan Manna Sugoroku tersebut. 


\section{Hasil dan Pembahasan}

Penelitian ini dilakukan 2 hari. Pada hari pertama tanggal 30 Agustus 2017 penulis memberikan materi pengantar (donyuu) agar mahasiswa dapat membuka pikirannya mengenai materi yang berhubungan dengan permainan Manna Sugoroku. Penulis memberikan materi PPT yang berisikan gambar-gambar sebagai kata kunci dalam permainan Manna Sugoroku. Seperti, gambar pintu karcis (改札口), kursi prioritas(優先 席), gerbong wanita, peron (ホーム) dan garis kuning.

Kegiatan pada hari pertama ini diikuti sebanyak 40 peserta yang sangat antusias karena selain memberikan contoh-contoh gambar bentuk larangan yang ada di dalam kereta Jepang, penulis juga memberikan video tentang pelanggaran di dalam kereta. Hal tersebut dapat terlihat dari komentarkomentar yang diberikan oleh mahasiswa ketika melihat gambar atau video yang disajikan. Adapungambar dan video yang disajikan kepada mahasiswa adalah gambargambar yang didapat dari Google. Sebagian besar mahasiswa program studi Pendidikan Bahasa Jepang FKIP Universitas Riau adalah mahasiswa yang berasal dari Riau sekitarnya, Sumatera Barat, Sumatera Utara dan daerah lain di Sumatera. Terutama mahasiswa yang berasal dari daerah Riau sekitarnya yang tidak memiliki jenis transportasi kereta membuat mereka merasa tertarik mengikuti kegiatan ini. Diakhir kegiatan pertama, penulis memberikan tugas tidak tertulis kepada mahasiswa yang hadir agar mereka mencari informasi sebanyak-banyaknya tentang kereta di Jepang, aturan-aturan yang yang harus dipatuhi oleh orang Jepang dan pelanggaran yang dilakukan oleh orang Jepang.

Pada hari kedua tanggal 31 Agustus 2017 adalah kegiatan inti dari penelitian ini. Mahasiswa yang hadir berjumlah 40 orang sama seperti pada kegiatan hari pertama. Pada hari tersebut mahasiswa dibentuk menjadi 10 kelompok yang beranggotakan 4 orang; terdiri dari 2 orang dari angkatan 2017 dan 2 orang angkatan 2016 yang dipilih secara acak. 1 orang dari angkatan 2016 tersebut adalah petugas penilai dalam permainan Manna Sugoroku.

Setelah dibagi menjadi 10 kelompok kemudian mahasiswa diperkenalkan dengan sugoroku yang permainannya sama dengan permainan yang pernah dimainkan oleh hampir seluh mahasiswa yangur hadir semasa kecil. Sehingga tidak terlalu memakan waktu yang lama untuk menjelaskan cara permainan sugoroku. Pada dasarnya permainan sugoroku ini tidak memiliki aturan yang baku sehingga setiap kelompok dapat menentukan cara permainannya masing-masing. Pada mulanya beberapa kelompok masih terlihat kebingungan dikarenakan mereka tidak terlalu paham mengenai papan permainan Manna Sugoroku yang diberikan. Hal tersebut dikarenakan (1) papan permainan yang sangat berbeda dengan yang pernah mereka mainkan. (2) papan permainan yang menggunakan hruuf Jepang. Kemudian penulis memberikan penjelasan sehingga mereka dapat memulai dan melanjutkan permainan. 


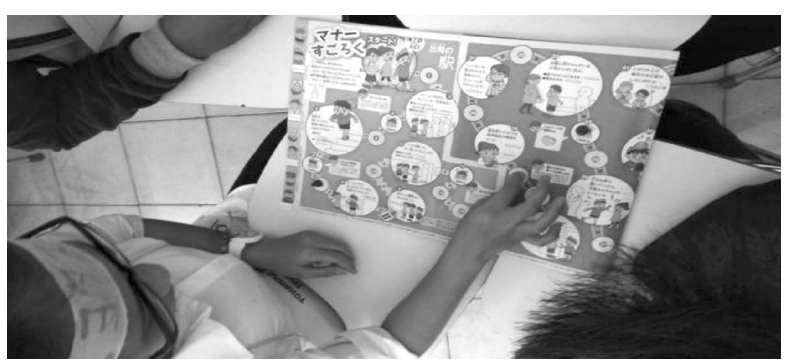

Gambar 3. Mahasiswa sedang bermain Manna Sugoroku

Oleh karena kegiatan pengenalan budaya Jepang melalui permainan Manna Sugoroku ini dilakukan secara berkelompok, mahasiswa sangat tertarik untuk memainkannya. Terlebih lagi, papan permainan yang mereka gunakan adalah papan permainan yang langsung penulis dapatkan ketika berkunjung ke Stasiun Kobe. Gambar pada papan permainan Manna Sugoroku tersebut sebenarnya diperuntukkan kepada anak-anak sekolah di Jepang sehingga dikemas dalam gambar yang menarik. Bagi pembelajar bahasa Jepang tingkat dasar khususnya mahasiswa program studi Pendidikan Bahasa Jepang membaca aturan permainan yang tertulis pada papan permainan memiliki kesulitan tersendiri. Terutama ketika mereka membaca huruf Kanji meskipun terdapat furigananya. Sebagian besar mahasiswa yang mengikuti kegiatan ini adalah mahasiswa yang pernah belajar bahasa Jepang di bangku SMA/SMK namun mereka masih mengalami kesulitan membacata huruf Jepang, hal tersebut dikarenakan oleh buku pegangan yang mereka gunakan semasa belajar di bangku SMA/SMK adalah buku yang menggunakan huruf latin.

Namun demikian, hal tersebut tidak membuat mahasiswa putus asa, semua kelompok dapat menyelesaikan permainan hingga selesai. Bagi mahasiswa yang mengalami kesulitan dalam membaca huruf Jepang maka 1 orang mahasiswa angkatan 2016 yang sudah mahir membaca diperbolehkan membantu untuk menjelaskan apa yang dimaksud oleh petunjuk permainan tersebut.

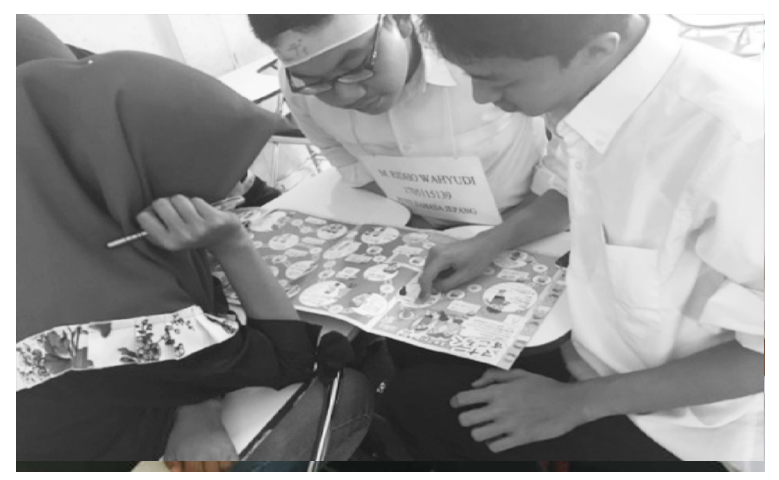

Gambar 4. Mahasiswa membaca petunjuk permainan

Kegiatan pengenalan budaya melalui permainan Manna Sugoroku ini dapat berjalan dengan lancar disebabkan karena adanya faktor yang mendukung berjalannya kegiatan tersebut. Hal tersebut dapat diidentifikasi melalui antusiasnya mahasiswa terhadap permainan Manna Sugoroku yang pertama kali mereka lihat.

Faktor yang mendukung kegiatan tersebut adalah ketertarikan mahasiswa untuk memahami aturan-aturan ketika menggunakan kereta di Jepang yang dapat mereka ketahui tanpa harus membaca buku, mendengar berita bahkan tanpa harus pergi ke Jepang terlebih dahulu. Mereka dapat mengetahuinya melalui permainan yang pernah dan mereka ketahui sebelumnya. Mahasiswa menjadi tahu bahwa masyarakat Jepang yang selama ini mereka ketahui adalah masyarakat yang berbudaya disiplin tetapi ketika menggunakan fasilitas umum 
aturan-aturan yang harus mereka patuhi tetap terpampang dengan jelas. Antusiasme mahasiswa dibuktikan dengan adanya komunikasi antar anggota kelompok karena sebelumnya mereka sudah ditugaskan untuk mencari informasi mengenai aturan menggunakan kereta di Jepang.

Seperti yang telah dipaparkan sebelumnya, bahwa mahasiswa program studi Pendidikan Bahasa Jepang FKIP Universitas Riau sebagian besar belum lancar membaca huruf Jepang dikarenakan ketika mereka belajar bahasa Jepang di SMA/SMK tidak menggunakan huruf Jepang. Huruf Jepang hanya dipelajari sebagai latihan tambahan saja.

Oleh karena itu, dalam kegiatan ini kurangnya kemampuan membaca huruf menjadi faktor penghambat dalam permainan ini. Seluruh kelompok mendapat porsi yang sama yaitu 2 orang mahasiswa baru angkatan 2017, yang baru saja diajarkan huruf hiragana dan huruf katakana. Sehingga permainan Manna Sugoroku memakan waktu selama lebih kurang 50 menit. Keterbatasan pengetahuan tentang aturan yang harus ditaati oleh orang Jepang dalam menggunakan fasilitas umum juga membuat pemain tidak dapat menjawab pertanyaan ketika bidak mereka berhenti pada kotak yang berisi pertanyaan. Namun demikian hal tersebut dapat diatasi ketika mahasiswa yang bertugas sebagai penilai memberikan penjelasan dan mengingatkan kembali tentang materi yang telah diberikan pada hari sebelumnya.

\section{Simpulan dan Saran}

\section{Simpulan}

Kegiatan pengenalan budaya Jepang melalui permainan Manna Sugoroku yang dilaksanakan dalam 2 hari dapat berjalan dengan baik. Seluruh mahasiswa memiliki minat yang kuat untuk mengetahui aturanaturan apa saja yang harus dipatuhi oleh orang Jepang ketika mereka menggunakan fasilitas umum terutama kereta. Pengetahuan yang mereka miliki ketika mendapat tugas untuk emncari informasi tentang aturan menggunakan kereta dapat mereka buktikan pada permainan Manna Sugoroku.

Usaha untuk dapat membaca huruf Jepang pada papan permainan dan menjawab pertanyaan serta memberikan penilaian benar atau salah pada pernyataan pada setiap kotak juga menimbulkan motivasi yang kuat bagi mahasiswa program studi Pendidikan Bahasa Jepang FKIP Universitas Riau untuk lebih meningkatkan kemampuan mereka.

Kegiatan penelitian ini dapat dikatakan berhasil karena adanya kesesuaian antara materi yang disampaikan pada hari pertama dan pengaplikasian materi tersebut pada permainan. Hal tersebut sesuai dengan apa yang telah mahasiswatulis pada kertas yang diberikan di akhir kegiatan. Sebagian besar dari mereka telah paham teori bahwa penggunaan media dalam pembelajaran sangat diperlukan untuk meningkatkan minat dan motivasi pembelajar tingkat dasar

\section{Saran}

Berdasarkan tulisan mahasiswa pada kertas yang diberikan di akhir kegiatan, sebagian besar mahasiswa program studi Pendidikan Bahasa Jepang FKIP Universitas Riau telah paham tentang aturan menggunakan kereta di Jepang. Mahasiswa 
juga menuliskan keinginan untuk lebih mengetahui tentang aturan-aturan yang ada di masyarakat Jepang lainnya. Dikarenakan permainan Manna Sugoroku tersebut menggunakan istilah yang baru didengar ataupun diketahui oleh mahasiswa tingkat 1 , ada baiknya juga digunakan untuk mahasiswa yang sudah mahir membaca teks berbahasa Jepang sehingga permainan tersebut tidak memakan waktu yang lama.

\section{Daftar Pustaka}

Soenjono Dardjowidjojo. 2003.

Psikolinguistik: Pengantar Pemahaman Bahasa Manusia. Jakarta: Yayasan Obor Indonesia.

FKIP Universitas Riau. 2014. Kurikulum Berbasis KKNI Program Studi Pendidikan Bahasa Jepang. Pekanbaru: Unri Press.

Enco Mulyasa. 2005. Menjadi Guru Profesional. Bandung: PT. Remaja Rosda Karya.

Hamzah B. Uno. 2011. Teori Motivasi \& Pengukurannya: Analisis di Bidang Pendidikan. Jakarta: Bumi Aksara.

Rusman. 2017. Belajar dan Pembelajaran: Berorientasi Standar Proses Pendidikan. Jakarta: Kencana.

Sardiman A.M. 2016. Interaksi \& Motivasi Belajar Mengajar. Jakarta: PT. RajaGrafindo Persada.

Sudjianto, \& Ahmad Dahidi. 2004. Pengantar Linguistik Bahasa Jepang. Jakarta: Kesaint Blanc.
The Japan Foundation. 2010. Nihongo Kyoujuhou Series: Nihonjijou Nihon Bunka wo Oshieru. Tokyo

Keigo no Shishin. Bunka Shingikai Kokugo Bunkakai.2007

www.bunka.go.jp/bunkashingikai/soukai/pdf /keigo tousin.pdf

Peranan Unsur Sosial Budaya dalam Pengajaran BIPA

https://www.ialf.edu/kipbipa/papers/Mustaki $\underline{\text { m.doc }}$ 